GEFAD / GUJGEF41(2): 1051-1080(2021)

\title{
Yükseköğretim Kurumlarının Finansmanı: Dünyadaki Uygulamalar İle Karşılaştırmalı Bir Analiz
}

\section{Financing of Higher Education Institutions: A Comparative Analysis With Practices in the World}

\author{
Bahar YAKUT ÖZEK ${ }^{1}$, Sait AKBAŞLI ${ }^{2}$ \\ ${ }^{1}$ Hacettepe Üniversitesi, Eğitim Bilimleri Enstitüsü, Eğitim Yönetimi Anabilim Dall. \\ yakutbah@gamil.com \\ ${ }^{2}$ Hacettepe Üniversitesi, Eğitim Bilimleri Enstitüsü, Eğitim Yönetimi Anabilim Dall. \\ sakbasli@gmail.com
}

Makalenin Geliş Tarihi: 09.12.2020

Yayına Kabul Tarihi: 14.05.2021

\begin{abstract}
$\ddot{O} Z$
Ülkelerin yüksekögrretimi kültürel kalkınma, toplumsal kalkınma ve ilerleme için itici bir güç olarak görmesi yükseköğretime katılımı evrenselleştirmiştir. Yükseköğretime katılımın evrenselleşmesiyle toplumun her kesiminden erişim sağlanması sistemde nicel büyümeyi tetiklemiş, bu büyüme ile birlikte kamu harcamaları da artmıştır. Kamu harcamalarındaki artış finans sorununu da beraberinde getirmiştir. Ülkeler bir taraftan yüksekögretim talebini karşılayabilmek için büyümeyi sürdürürken diğer taraftan finans sorununu çözmek amactyla finans kaynaklarının çeşitlenmesine yönelik alternatif uygulamalar üretmişlerdir. Bu çalışmanın amacı da Türkiye'de yükseköğretimin finansmanı konusunda oluşan mali güçlükleri aşmak, kamu dışı kaynak bulmak ve kaynakları çeşitlendirmek adına yükseköğretim finans sistemi açısından farklılıklar gösteren ülkelerin finans modellerini incelemek ve Türkiye için önerilerde bulunmaktır. Bu kapsamda yükseköğretim finans sistemi açısından farklılıklar gösteren dört farklı sistem parametresi ölçüt alınmıştır. Bu parametreler doğrultusunda da Amerika, İngiltere, Japonya ve Türkiye'nin finans modelleri ve kaynakları incelenerek mevcut durumları ortaya konmuş ve Türkiye yükseköğretim finans sistemi için önerilerde bulunulmuştur.
\end{abstract}

Anahtar Sözcükler: Yükseköğretim, Yükseköğretim finansmanı, Yükseköğretim maliyeti

\footnotetext{
*Alıntılama: Yakut-Özek, B. ve Akbaşlı, S., (2021). Yükseköğretim kurumlarının finansmanı: dünyadaki uygulamalar ile karşılaştırmalı bir analiz. Gazi Üniversitesi Gazi Eğitim Fakültesi Dergisi, 41(2), 1051-1080.
} 


\begin{abstract}
Countries' perception of higher education as a driving force for cultural development, social development and progress has universalized participation in higher education. The access to higher education from all segments of the society has triggered quantitative growth in the system, and with this growth public spending has increased. The increase in public expenditures brought with it the finance problem. On the one hand, countries have continued to grow in order to meet the demand for higher education. On the other hand they have produced alternative practices to diversify their financial resources in order to solve the financial problem. This study aims to examine the financial models of the countries which differ in terms of higher education finance system and make recommendations to Turkey in order to overcome financial difficulties that occur in the financing of higher education in Turkey, to find non-public sources and to diversify sources. In this context, four different system parameters differing in terms of higher education financial system were taken as criteria. In line with these parameters, the financial models and sources of the United States, England, Japan and Turkey were examined, their current situation was revealed and recommendations were made for the Turkish higher education financial system.
\end{abstract}

Keywords: Higher education, Higher education finance, Higher education cost

\title{
GíRiş
}

Eğitim bireylerin dünyadaki yerini bulması, dünyayı anlaması, anlayış ve değerlerini başkalarına aktarması için önemli bir araç olduğu gibi; özellikle yükseköğretim, bireysel büyüme, toplumsal ilerleme ve kültürel kalkınma için itici bir güç olarak görülebilir. Eğitim, kültürel kalkınmanın yanı sıra ekonomik kalkınmaya da katkıda bulunmaktadır. Ekonomik kalkınmanın nihai amacı ise bireysel refahı desteklemek, toplumsal eşitliği teşvik etmek ve devletin vatandaşlarının isteklerini yerine getirmesini sağlamaktır (Hunt, 2011). 2547 sayılı Yükseköğretim Kanunu'nun 4. maddesinde yükseköğretimin amacı benzer şekilde vatandaşlarının refah seviyesini artırmak, hür ve bilimsel düşünce gücüne ve geniş dünya görüşüne sahip, insan haklarına saygıll, ilgi ve yetenekleri doğrultusunda ülke ihtiyaçlarına ve kalkınmasına cevap verebilecek, ülke kalkınmasına destek olabilecek bireyler yetiştirmek olarak belirtilmektedir (YÖK, 1981). Bunlar aynı zamanda Türkiye yükseköğretim sisteminin hükümet, iş dünyası ve toplum ile ortaklaşa yürüttükleri sistem düzeyinde hedefleri olarak 1984 yılında ilk defa beşinci beş yıllık kalkınma planında belirlenmiş hedeflerdir (DPT, 1984). Shapiro (2005), yükseköğretim kurumlarının kendi kendine hizmet etmelerinin ötesine geçerek kamusal amaca hizmet etmelerinde ve arzulanan bir toplumsal düzene ulaşmalarında sosyal değişimi zorlama ihtiyaçlarını vurgulamaktadır. 
Yükseköğretim hem bireylere hem de sosyal ve ekonomik açıdan toplumlara yarar sağladığından gelişmiş ve gelişmekte olan ülkelerde yükseköğretime talepler artmakta ve bu talebin karşılanması noktasında yatırımların da değerlendirilmesi gerekmektedir (Kurul, 2012). Üniversiteler için, kuruldukları andan itibaren diğer sosyal kurumlarla, bazen destekleyici, bazen de eleştirel olarak yakın ilişsi içindedirler. Ancak yükseköğretim kurumları modernleşme sürecinde, diğer sosyal ve ekonomik kurumların zamanla değişen beklenti ve ihtiyaçlarına uyum sağlamak ve taleplerini karşılamak için değişimler yaşamıştır (Brennan, 2002). Brennan (2004) bu değişimleri üç evrilme döneminde incelemiştir. İkinci dünya savaşına kadar olan sürede üniversitelerin seçkinlere hitap ettiğini, seçkin sınıfın rollerine hazırlık yerlerinin üniversiteler olduğunu "seçkinler dönemi”, ikinci dünya savaşı ile 1980 yılları arasını ise geniş bir teknik ve ekonomik seçkin rollere hazırlık yeri olarak " kitlesel dönem” olarak ifade etmiş, en son ise 1980 ve sonrasını tüm nüfusun teknolojik değişime adaptasyonu olarak "evrensel dönem” diye ayırmıştır. Throw (2007) 2030 yılından sonra yüksek öğretim ortamında, geçmişten günümüze olandan çok daha fazla değişim meydana geleceğini, üniversitelerin sayısı artarken paydaş kurum türü de artacağını, öğrenci ve öğretim elemanı sayısı artarken çeşitliliğin de artacağını iddia etmektedir. Sistemin çeşitlenerek toplumun her kesimine açılması ile yükseköğretim sistemi hızlı bir büyüme yaşamış ve bu büyüme kamu harcamalarında da kritik bir artışa neden olmuştur (Çetinsaya, 2014). Dolayısıyla üniversiteler hızlı büyümeleri nedeniyle mali planlamaları açısından git gide kamu harcamalarına daha fazla bağlı olmaktadırlar (Adem, 2008).

Yükseköğretim, işlevini ekonominin egemen olduğu dijital bilgiye dayalı bir toplum altına yerleştirir. Günümüzde işgücü piyasaları, teknolojik yeterlilik ve eleştirel düşünme, çoklu görev ile karmaşık problem çözme gibi becerilere ihtiyaç duymakta, bu da rekabeti arttırmaktadır (Westerheijden, Stensaker ve Rosa, 2007). Dolayısıyla, yükseköğretim sisteminde araştırmaya dayalı ve yeniliklerden oluşan, düzgün çalışan ve herkesin becerilerinin geliştirilmesine olanak sağlayan "bilgi üçgeninin" yaratılması istihdam, eşitlik ve sosyal içerme açısından gereklidir (Lung ve Alexandra, 2012). Yükseköğretim kademesi yüksek nitelikli insan gücü yetiştirme de önemli bir aşamadır. Üniversitelerde 
mesleki öğretimin var olması kuram ve uygulamanın bir arada kullanılması toplumsal kalkınma açısından oldukça önemlidir (Adem, 2008). Kalkınmanın kilit bileşenlerinden biri olan yükseköğretimin de en önemli konularından biri finansmandır (Hunt, 2011).

Günümüzde neoliberal ekonomik yapı içerisinde bireyler, devamlı olarak yükseköğretimden daha fazla yararlanmayı talep etmektedir (Yılmaz ve Sarpkaya, 2016). Yükseköğretime talep arttıkça yükseköğretimin maliyeti de artmaya devam etmektedir (Jacob, Neubaur ve Ye, 2017). Ayrıca yükseköğretim kurumlarında araştırma gereksinimleri, büyük kütüphaneler ve laboratuvarlar düşük öğretim ücretleri üniversitelerin maliyetini arttırmaktadır (Throw, 2005). Yükseköğretimin finansmanı, eğitimin finanse edilmesi ve bu fonların en verimli şekilde kullanılması ve bu hizmetlerin sunulmaya devam edilebilmesi için gerekli mali ve maddi kaynakların sağlanması süreci olarak tanımlanabilir. (Karakütük, 2006). Dolayısıyla yükseköğretim sistemleri üzerinde finansman sorunu yüseköğretimin maliyetinin karşılanması noktasında cevap aranan ve çözüm bekleyen bir konu olarak değerlendirilmektedir (Altbach, Reisberg, ve Rumbley, 2009; Güngör ve Göksu; Johnstone, 2003; Marginson, 2017; Şenses, 2007; Tekeli, 2010; Woodhall, 2007). Bu bağlamda farklı kaynaklardan bir tanesi olan özelleşme ilk olarak Şili'de denenmiş (Kurt, 2021), birçok ülkede finans kaynaklarının çeşitlenmesiyle dünyaya yayılmıştır (Arastaman, 2020). Özel yükseköğrenimin dünya çapında büyümesi, son birkaç on yılın en dikkat çekici gelişmelerinden biri olmuştur. Özel yüksek öğretim birçok ülkede var olmuştur ve geleneksel olarak Japonya, Kore Cumhuriyeti ve Filipinler gibi Doğu Asya ülkelerinde baskın güç olmuştur (Altbach, Reisberg, ve Rumbley, 2009). Özel sektör çoğu ülkede yükseköğretimin küçük bir bölümünü temsil ederken, çoğu kar amacı gütmeyen veya yarı kar amaçlı olan özel kurumlar artık dünya çapında en hızlı büyüyen sektörü temsil etmektedir. Özel sektör şu anda Meksika, Brezilya ve Şili gibi ülkelerde öğrenci nüfusunun yarısından fazlasını eğitmekte ve Orta ve Doğu Avrupa'da, eski Sovyetler Birliği ülkelerinde ve Afrika'da hızla genişlemektedir. Çin ve Hindistan da önemli özel sektörlere sahiptir (Altbach, 2005; Reisz, 2007).

Dünya Bankası ve sivil toplum kuruluşlarının yardımlarıyla finanse edilen eğitim projeleri, gelişmekte olan birçok ülkede eğitimde özelleşmeyi destekleyerek ülkelerin iç 
politikalarını şekillendiren ve uluslararası politikaları etkileyen bir güç haline gelmiştir (Psacharopoulos, Tan ve Jimenez, 1986). Dolayısıyla Türkiye'de 1965 yılında çıkarılan 625 sayılı Özel Okullar yasasından sonra özel okulların sayısı hızla artmıştır (Tekeli, 2010). Bu kapsamda özel üniversitelerin sayısı artarken, devlet üniversiteleri daha az kamu kaynağı kullanmaya ve kamu dışı kaynak bulmaya özendirilmekte, hatta kendi öz kaynaklarını geliştirmeye teşvik edilmektedir (Çetinsaya, 2014). Bu bağlamda Türkiye'de yükseköğretimin finansal olarak birtakım zorluklarla yüz yüze kaldığı söylenebilir. Bu çalışma yükseköğretim finansmanı konusunda oluşan mali güçlükleri aşmak, kamu dışı kaynak bulmak ve finans modelini çeşitlendirmek adına Türkiye'nin ve yükseköğretim finans sistemi açısından farklılıklar gösteren ülkelerin finans modellerini ve kaynaklarını incelemeyi ve mevcut durumu ortaya koymayı amaçlamaktadır.

\section{YÖNTEM}

Araştırmada finans sisteminin çeşitliliğini analiz etmek amacıyla araştırma kapsamında Garritzmann'ın (2016) 33 ülkede 1995-2015 yılları arasındaki öğrenci-yardım sisteminin 70’den fazla özelliğinin sistematik olarak karşılaştırılarak belirlediği dört finans parametresi ölçüt alınmış ve incelenen ülkeler bu parametrelere göre seçilmiştir. $\mathrm{Bu}$ parametrelere göre yükseköğretimde eğitimi finanse eden dört farklı sistem bulunmaktadır. Birinci sistem neredeyse hiçbir öğrenim ücreti ödemeyen ya da çok düşük bir mali öğrenci desteği olan ülkeleri kapsamaktadır. Bu grupta Almanya gibi birçok Avrupa ülkesi yer almaktadır. Türkiye hiçbir öğrenim ücreti ödemeyen ya da çok düşük bir mali öğrenci desteği olan sisteme dâhildir, bu nedenle birinci sistem kapsamında incelenmiştir. İkinci sistemde öğrenciler, öğrenci sübvansiyonları şeklinde cömert bir kamuoyu desteği almakta, dolayısıyla herhangi bir öğrenim ücreti ödememektedir. $\mathrm{Bu}$ kategoride Norveç ve Finlandiya gibi İskandinav ülkeleri bulunmaktadır (Garritzmann, 2016). Bu ülkeler eğitim alan nüfus ve ekonomik göstergeler açısından ortalama değerlerden daha yüksek bir değere yani eğitim harcamalarının gayrisafi yurt içi hasılaya (GSYİH) oranında OECD ülkelerinden farklılık göstermektedir. OECD ülkelerinde ortalama 5.2 iken Finlandiya'da 5.7 ve Norveç' te 6.2'dir (OECD, 2017b). Bu oranlar 
OECD ortalamasından farklı olduğu için karşılaştırmada incelemeye dâhil edilmemiştir. Yükseköğretim finans sisteminin üçüncü kategorisi, öğrenciye sunulan yüksek düzeyde öğrenim ücreti, kredi ve hibe alternatifleri ile karakterize edilmektedir. Çoğu AngloSakson ülkesi, Birleşik Devletler ve İngiltere de dâhil olmak üzere bu gruba girmektedir (Garritzmann, 2016). Bu sistem kapsamında ABD ve İngiltere yükseköğretim finansman modelleri incelenmiştir. Dördüncü sistemde ise öğrenciler yüksek bir öğrenim ücreti ödemekte, dahası alternatif herhangi bir kamuya açık öğrenci destek uygulaması da bulunmayan sistemdir. Bu sistem kategorisinde bazı Latin Amerika ülkeleri, Japonya ve Güney Kore'de bulunmaktadır. $\mathrm{Bu}$ sistem kapsamında da araştırmada Japonya yükseköğretim finans sistemi analiz edilmiştir.

Araştırma mevcut olan bir durumu, olduğu gibi açıklamayı amaçlayan bir araştırma yaklaşımı olan betimsel tarama modelinde tasarlanmıştır (Karasar, 1999). Verilerin toplanmasında belgesel tarama yöntemi kullanılmıştır. Belgesel tarama, belirli bir amaca yönelik olarak, kaynakları bulma, okuma, not alma ve değerlendirme işlemlerini kapsamaktadır (Karasar, 2013). Bu doğrultuda Türkiye, ABD, İngiltere ve Japonya'nın yükseköğretim finansal sistemleri ile ilgili kitap, tez, makale, dergi, seminer raporları, kalkınma planları gibi bilimsel kaynaklar incelenmiştir ve finans sistemleri analiz edilmiştir. Araştırmada bu analizler neticesinde, yükseköğretim finans sistemi açısından farklılıklar gösteren dört ülkenin finans modelleri ve kaynakların mevcut durumu ortaya konmuş, Türkiye yükseköğretim finans modelinin iyileştirilmesi ve geliştirilmesi adına önerilerde bulunulmuştur.

\section{Türkiye’de Yükseköğretim Finansmanı}

Türkiye'de eğitim büyük ölçüde kamusal olarak finanse edilse de (Kurul, 2012) kaynaklarının sınırlı olmasından dolayı her alana sınırsız bir kaynak aktaramaz (Gölpek, 2011; Meriç, 1998). Eğitime ayrılan kamu kaynakları nüfusun artmasıyla birlikte eğitime de artan talep nedeniyle eğitim hizmetlerinin sunumuna yetmemiş ve eğitim sisteminde karşılaşılan parasal zorluklar için eğitim yöneticileri özel finansal kaynaklar aramaya başlamıştır (Kurul, 2012). Bireylerin getiriler açısından yaşamlarını en çok etkileyen eğitim kademesinin yükseköğrenim olması yükseköğrenime talebi arttırmaktadır (Baum 
ve Payea, 2005). Yükseköğrenimde talep-arz açı̆̆ının karşılanması ve büyümenin sürdürülebilmesi için yükseköğretimin finansman kaynaklarının çeşitlenmesi ve özelleşmeye doğru kayması ile finansman sorunu çözülmeye çalışılmıştır (Arastaman, 2020).

Türkiye'de yükseköğretim finansman sistemine yönelik anayasanın 130. maddesinde her düzeydeki yükseköğretimin finansmanının kamu hizmeti niteliği taşıdığı belirtilmektedir. Devlet üniversiteleri de, vakıf üniversiteleri de kanunla kurulmakta, kamu tüzel kişisi özelliğini taşımakta ve kamu yönetim ve denetim organlarının akademik, idari ve mali gözetim ve denetimi altında kamu hizmeti sunmaktadır. Kamu hizmeti niteliği taşıyan yükseköğretimin finansmanı, devlet ve vakıf üniversiteleri itibariyle iki temel yöntemle yapılmaktadır. Bunlar anayasal olarak devlet üniversitelerinde kamusal finansman, vakıf üniversitelerinde ise özel finansman sistemi olarak benimsenmiştir (TCA, 1982). Mevcut 2547 sayılı YÖK Kanunu'nda ise yükseköğretimin finansmanı 55 ve 56. maddelerde düzenlenmiştir. 55. Maddede yükseköğretim kurumlarının gelir kaynaklarına yer verilmiştir. Bu maddeye göre yükseköğretim kurumlarının gelirleri Şekil 1'de görüldüğü gibidir:

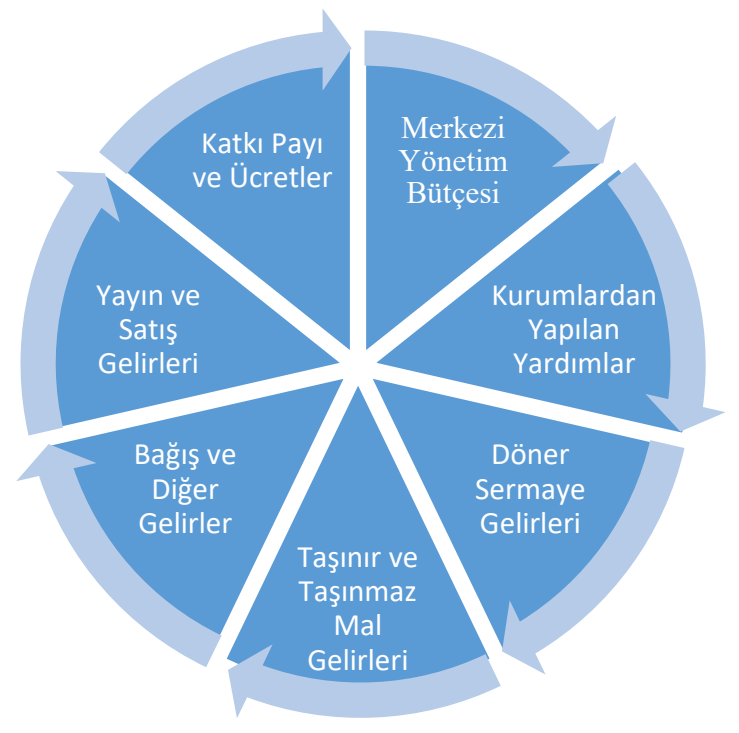

Şekil 1. Türkiye'de Devlet Yükseköğretim Kurumlarının Finansman Kaynakları 
Şekil 1'de görüldüğü gibi yükseköğretim kurumlarının finans kaynakları; her yıl bütçeye konulacak ödenekler, kurumlarca yapılacak yardımlar, alınacak harç ve ücretler, yayın ve satış gelirleri, taşınır ve taşınmaz malların gelirleri, döner sermaye işletmelerinden elde edilecek kârlar, bağışlar, vasiyetler ve diğer gelirler olarak belirtilen kalemlerden oluşmaktadır (Altundemir, 2015). Ocak 2013'te Yeni Yükseköğretim Kanunu Taslağı'nda (Baskan ve Sencer, 2014) yükseköğretimin finansmanı konusunda yeni düzenlemeler önerilerek, 66, 67, 68 ve 69. maddede mali hükümlere yer verilmiştir. 66 . maddede Türkiye Yükseköğretim Kurulu ile devlet yükseköğretim kurumlarının özel bütçe gelir kaynakları belirtilmiştir. Bu kaynaklar; (i) Devlet katkı payı (ii) Hazine yardımı (iii) Öğrenci katkı payları ve ögrenim ücretleri (iv) Basılı ya da görsel ders malzemeleri, kitap ve yayın satış gelirleri (v) Taşınır ve taşınmaz mal gelirleri (vi) Döner sermaye işletmelerinden aktarlacak tutarlar (vii) Băğş, yardım ve diğer gelir'dir. Tasarının 67. maddesinde devlet yükseköğretim kurumlarının giderlerinin karşılanması, devlet katkı payı, öğrenci katkı payı ve öğrenim ücretinin tanımları yapılmış; 68. maddede yükseköğretim kurumlarına sağlanacak mali kolaylıklar düzenlenmiş ve 69. maddede ise döner sermaye ile ilgili detaylara yer verilmiştir (Yeni YÖK Tasarısı, 2013). Ancak bu yasa taslağı taslak olarak kalmış kabul görmemiştir. Yükseköğretim kurumlarının finansal olarak daha esnek bir yapıda olabilmeleri ve kaynakları çeşitlendirebilmelerine imkân sağlayan bir taslak metin olduğu düşünülebilir.

Devlet üniversitesi bütçeleri de 5018 sayılı Kamu Malî Yönetimi ve Kontrol Kanunu’na göre özel bütçelidir. Üniversite özel bütçesi; kamu hizmeti yürütmek amacıyla kurulan, kaynak tahsisi yapılan, harcama yetkisi olan, kuruluşu ve işleyişi özel yasayla düzenlenmiş olan bütçedir. Devlet üniversitelerinin merkezi yönetim bütçesine tabi olması; bütün gelir ve giderleri bütçede göstermesi, gelir ve gider denkliğini sağlaması, bütçeyle verilen harcama yetkisinin yasalarla belirlenen görevlerin yerine getirilmesi amacıyla kullanılmasını esas almaktadır. Yükseköğretime sağlanan kamu finansmanının bütçe istek ve tahsisine ilişkin akış Şekil 2'de gösterilmektedir (Ateş, 2013). 


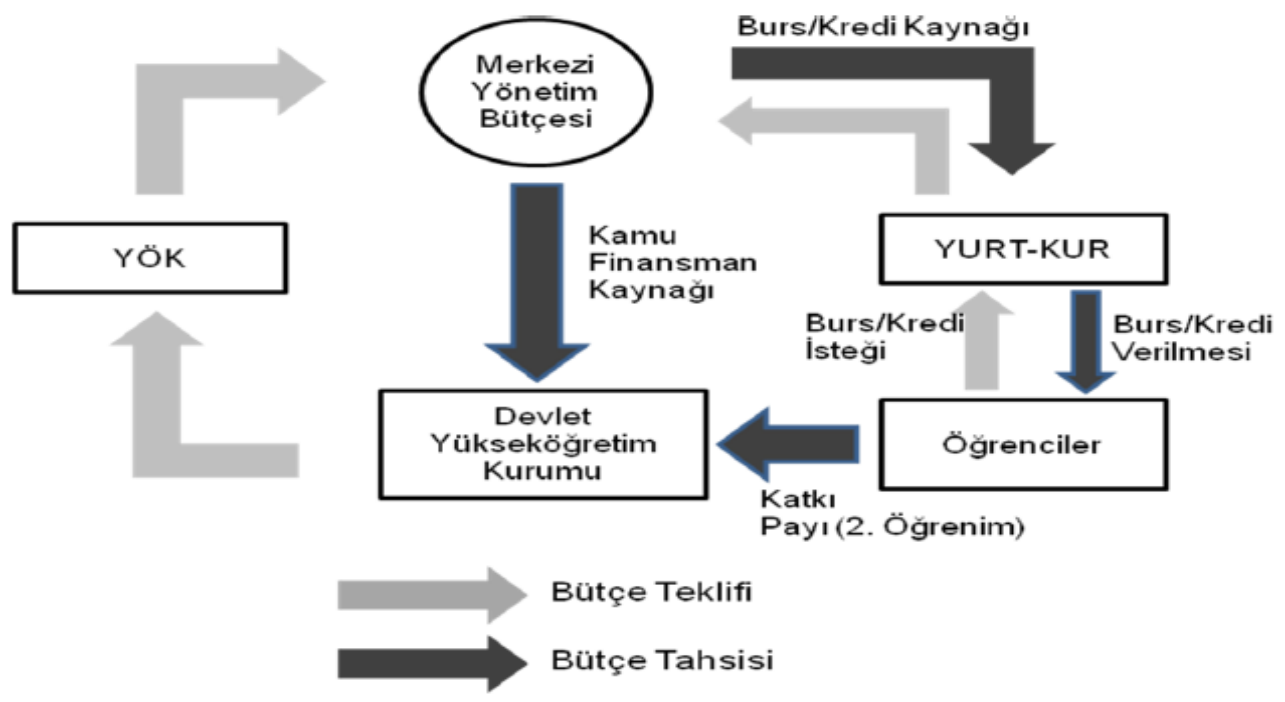

Kaynak: Ateş, 2013

Şekil 2. Türkiye'de Kamu Finansman Kaynağı Akış Şeması

Şekil 2'de görüldüğü gibi, yükseköğretim kurumları, bütçe tekliflerini hazırlayarak onaylanmak üzere YÖK'e göndermektedir. YÖK'ün onayını takiben teklif, değerlendirilmek ve yasalaşmak üzere Maliye Bakanlığına gönderilmektedir. Öğrencilere burs ve/veya kredi olarak ayrılan kaynaklar ise YURTKUR (Yüksek Öğrenim Kredi ve Yurtlar Kurumu)'a tahsis edilmektedir. Öğrencilerin talebi üzerine YURTKUR, mevzuata uygun olarak değerlendirmeyi yapmakta ve öğrencilere istenen krediyi vermektedir (Ateş, 2013). Öğrencileri maddi olarak finanse eden YURTKUR ise 1961 yılında 351 sayılı kanuna göre Başbakanlığa bağlı olarak kurulmuştur. YURTKUR'un amacı yurt içinde ve dışında yükseköğretim gören öğrenciler için yurtlar yapmak ve bunların işletmesini sağlamak, beslenme yardımı yapmak, eğitim, sosyal, kültürel ve sportif faaliyetlerle milli ve manevi gelişmelerine katkı sağlamak, yükseköğretim öğrencilerine kredi veya burs vermek, öğrencilerin yükseköğretimlerini kolaylaştırmaktır (351 sayılı KYK Kanunu, 1961).

YURTKUR tarafından öğrencilere verilen kredi kanunda öğrenim kredisi olarak nitelendirilmektedir. Öğrencilerin kredi borcu, öğrenim kredilerinin verildiği tarihten 
öğrenim süresi bitimine kadar geçen sürede veya herhangi bir sebeple kredisinin kesildiği tarihe kadar öğrenim kredisi olarak verilen miktarlara, Devlet İstatistik Enstitüsünün toptan eşya fiyat endeksindeki artışlar uygulanarak hesaplanacak miktarın ilave edilmesi suretiyle tespit edilmektedir. Öğrenci, borcunu öğrenim gördüğü öğretim kurumunun normal eğitim süresinin bitiminden itibaren iki yıl (öğrencinin lisansüstü eğitim yapması halinde dört yıl) sonra başlamak üzere, kredi aldığg sürede ve aylık dönemler hâlinde kuruma ödemek zorundadır (351 sayılı KYK Kanunu, 1961). Ekonomik durumu yerinde olmayan öğrencilere de kredi ile aynı oranda öğrenim desteği sunulmakta, fakat tek farkı geri ödemesinin alınmamasıdır.

Çınar ve Ağcakaya'ya (2016) Türkiye'de barınma ve kredi faaliyetlerini yürüten YURTKUR'un yükseköğretimin dolaylı kamu finansmanı yanını oluşturan gelir ve harcamalarını, yükseköğretimin finansmanı altında ele almak yaygın değildir, fakat bu uygulama Batı ülkelerinde yükseköğretim finansmanı içinde yer almaktadır. $\mathrm{Bu}$ uygulama öğrencilere sağlanan öğrenim, barınma ve katkı kredileri konusunda aldıkları hizmetin finansmanına katkı sağlama olarak düşünülebilir (Akça, 2011). Gelir dağılımının adaletsizliğinden kaynaklı olarak yükseköğretime devam etmekte zorluk çeken öğrenciler için eşitsizliğin giderilmesi noktasında aile geliri temele alan uygulamalara odaklanılabilir (Kavak, 2011).

Yükseköğretim finansman kaynaklarından bir diğeri ise üniversite-sanayi işbirliği ile elde edilmektedir. Üniversite-sanayi işbirliği olarak bilim adamlarının girişimcilik faaliyetleri hiçbir şekilde yeni fenomenler değildir. İlk olarak 17. yüzyıl Alman eczacılık biliminde başlamıştır. Bir başka ünlü örnek ise Justus Liebig'in 19. yüzyılın ortalarında gerçekleştirdiği gübre girişimidir (Etzkowitz, 1983). Türkiye'de üniversite-sanayi ilişkileri ilk olarak birinci beş yıllık kalkınma planında (1963-67) yer alarak özellikle kimya sanayinin geliştirilmesi için üniversite ve yatırımcı işbirliğinin destekleneceği belirtilmiştir (DPT, 1963). Üniversitelerin bilimsel araştırmalarını desteklemek amacıyla TÜBİTAK 1963 yılında kurulmuştur (Tekeli, 2011). TÜBİTAK üniversiteler ile sanayinin uygulamalı araştırmalar yapmak ve birlikte çalışacakları platformlar oluşturmak amacı ile 1996'da Üniversite-Sanayi Ortak Araştırma Merkezleri Programı 
(ÜSAMP) başlatmıştır. Program ile sanayi sektörü kaynaklarının ve devlet desteklerinin, Üniversite-Sanayi işbirliğini destekleyen ve sanayinin ihtiyaç duyduğu konulardaki araştırma faaliyetlerinde kullanılması hedeflenmiştir. Üniversite-Sanayi Ortak Araştırma Merkezleri (ÜSAM)'nin üniversitenin uygun göreceği alanda kurulması öngörülmüş, merkezlerin faaliyet göstereceği teknoloji alanı sanayici kuruluşlar ile ortak belirlenmiştir (Kiper, 2010). Kurulan merkezlere TÜBİTAK tarafından verilen desteğin süresi en fazla beş y1l olup, kurulan merkezlerin beş yılın sonunda desteksiz bir şekilde faaliyetlerini yürütebilmeleri hedeflenmiştir (Alkan, 2009). Program 2006 yılında sonlanmasına rağmen, Tablo 1'de de görüldüğü gibi kurulan üniversite-sanayi işbirlikli araştırma merkezleri faaliyetlerine devam etmektedir.

Tablo 1. Üniversite-Sanayi Ortak Araştırma Merkezleri

\begin{tabular}{|c|c|c|c|}
\hline Merkez & Ortak Üniversite & $\begin{array}{l}\text { Kuruluş } \\
\text { Y1lı }\end{array}$ & Faaliyet Durumu \\
\hline $\begin{array}{l}\text { Seramik Araştırma } \\
\text { Merkezi (SAM) }\end{array}$ & Anadolu Üniversitesi & 1998 & Faaliyette \\
\hline $\begin{array}{l}\text { Adana Üniversite-Sanayi } \\
\text { Ortak Araştırma } \\
\text { Merkezi (ÜSAM) }\end{array}$ & Çukurova Üniversitesi & 2000 & Faaliyette \\
\hline $\begin{array}{l}\text { Tekstil Araştırma } \\
\text { Merkezi (TAM) }\end{array}$ & Ege Üniversitesi & 2002 & $\begin{array}{l}\text { Faaliyeti } \\
\text { durdurulmuştur }\end{array}$ \\
\hline $\begin{array}{l}\text { Otomotiv Teknoloji ve } \\
\text { Ar-Ge Merkezi (OTAM) }\end{array}$ & $\begin{array}{l}\text { İstanbul Teknik } \\
\text { Üniversitesi }\end{array}$ & 2003 & Faaliyette \\
\hline $\begin{array}{l}\text { ODTÜ-OSTIM İleri } \\
\text { İmalat Sistemleri } \\
\text { Merkezi (ODAGEM) }\end{array}$ & $\begin{array}{l}\text { Orta Doğu Teknik } \\
\text { Üniversitesi }\end{array}$ & 2004 & Faaliyette \\
\hline $\begin{array}{l}\text { Biyomedikal } \\
\text { Teknolojiler Merkezi }\end{array}$ & Hacettepe Üniversitesi & 2004 & Faaliyette \\
\hline
\end{tabular}

Kaynak: Kiper, 2010

Teknoloji Merkezlerinin (TEKMER) açılması ve faaliyette olmasını sağlayan üniversitesanayi işbirliğinin diğer bir yansıması olan Teknoloji Geliştirme Bölgeleri (TGB) uygulaması da Türkiye'de kısa zamanda hızlı bir büyüme göstermiştir (Yıldırım ve Kaya, 2019). Amacı üniversitelerde temel bilimleri pazarlanabilir yeniliğe dönüştürmek olan TGB, genel olarak üniversite arazilerinde faaliyet göstermektedir. TGB aracılığıyla 
işletmeler üniversitelerin altyapılarından yararlanarak nitelikli ticari ürün ve hizmet elde edebilecekleri ileri teknoloji uygulamalarını geliştirmektedir. Bu kapsamda üniversiteler, TGB'de küçük çapta olan teknoloji şirketlerine ve girişimcilere araştırma yapacakları fiziki alan ve hizmet sunmakta, buna karşın gelecekteki araştırmalarını yürütebilmek amacıyla fon sağlayarak alternatif ve yeni bir gelir kaynağı oluşturmaktadır (Çaltekin, 2017). İlk TGB 1952 yllında ABD'de kurulmuş olan Stanford Research Park olup, ilerleyen yıllarda İngiltere ve diğer sanayileşmiş ülkelerin de kendi TGB'ni kurdukları görülmüştür (Alkan, 2009). Türkiye'de ise teknoloji geliştirme bölgesi kurma çalışmaları 1980'lerde başlamış, 1990'larda KOSGEB ile üniversitelerin işbirliği çerçevesinde teknokentlerin ilk adımı olarak öncelikle TEKMER (Teknoloji Merkezleri)'ler kurulmuştur. 2001 yılında yürürlüğe giren 4691 sayılı "Teknoloji Geliştirme Bölgeleri Kanunu" ile TGB'nin kurulmasına ilişsin mevzuat hazırlanmış, Nisan 2017 itibariyle de 65 TGB Bakanlar Kurulu Kararı ile ilan edilmiş̧ir. Fakat bu 65 teknokentin 53 adedi faaliyette olup diğerleri gelişme aşamasındadır (ODTÜ, 2017).

Türkiye'de yükseköğretim finansmanının \% 74.8'i kamudan, \% 24.9'u özel kaynaklardan ve \% 12.4'ü hane halkından karşılanmaktadır. Türkiye'de bir üniversite öğrencisinin kişi başı eğitim harcaması 8.901 \$ iken, gayri safi yurt içi hasılaya (GSYIH) göre GSYIH'ye oranı ise $1.65^{\prime}$ dir (SSekil 3). Yükseköğretim finansmanının yüksek oranda kamudan karşılanıp da öğrenci başına düşen eğitim harcaması OECD ortalamasının altında olan ülkelerden biri olan Türkiye, kamu harcaması düşük olmasına rağmen öğrenci başına düşen eğitim harcaması yüksek olan, gelişmiş ekonomiye sahip ABD, İngiltere ve Japonya gibi ülkelerle rekabet etmek durumundadır.

\section{ABD'de Yükseköğretim Finansmanı ile İlgili Bulgular}

Amerika'da ilk üniversite olan Harvard Üniversitesi on yedinci yüzyılda (1636) kurulmuş (Bevis, 2019; Lucas, 2006; Zubatsky, 2007;), ardından farklı dini ve politik ideolojileri temsil eden William and Mary College, Yale College ve New Jersey üniversiteleri açılmıştır ve saygınlıkları gün geçtikçe artmıştır (Bevis, 2019; Lucas, 2006) . Bu vakıf okullarının ana amacı kamu yararı adına bilimsel faaliyet yürütmek değil, çeşitli siyasi/dini projeleri hayata geçirmek olmuştur (Gür, 2016). Dini ve politik ideolojisi olan 
zümreler, çıkarlarının devlet mekanizmasında temsil edilmesi için üniversiteleri kendileri finanse etmiştir (Lucas, 2006). Öncelikli amaçları da varlıklı ailelerin çocuklarını, yani çağın elitlerini yetiştirmektir. Fakat 19. yüzyılda üniversiteler, devletleşmeye başlayan ABD’nin küresel dengelerdeki yerini bulma çabalarına yönelik olarak gelişmiş, bu gelişim Amerikan şirketlerine açılmış onlarca ulusal pazarın ve yeniden inşası gereken Avrupa ülkelerinin yarattığı talep patlamasını karşılamak için gerekli eğitimli insan gücünü temin etmeye odaklanmıştır (Palmedessa, 2017). Süreç içinde on dokuzuncu yüzyılın elit yetiştiren okullarının yerini nitelikli işçi ve teknisyen yetiştirme amacıyla kurulan devlet üniversiteleri almış, buna karşın vakıf üniversiteleri prestijli konumlarını sürdürerek elit kültürünün devamını garanti altına almıştır (Balaban, 2012).

Elitizmin on dokuzuncu yüzyılda kırılması ve her kesimden öğrencinin yükseköğretime erişmesi ile yükseköğretimin kamusal bir hak olmamasından dolayı ABD’de 1940-1960 yılları arasında çeşitli Öğrenci Kredi Programları uygulamaları başlamıştır (Zhou ve Mendoza, 2017). Doğrudan öğrenci yardımı kavramını 'her tür yükseköğrenimdeki tüm mali açıdan muhtaç öğrencilere' getiren Temel Eğitim Fırsatı Hibe Programı (BEOG), 1972 Federal Eğitim Değişikliği’ne dâhil edilmiştir (Bergen ve Zielke, 1979). İlerleyen y1llarda Eyalet Öğrenci Teşvik Bursları (State Student Incentive Grants; SSIG) gibi öğrenci teşvik bursları ile de öğrencilerin yükseköğretime katılımları için farklı seçenekler sunulmuştur (Lee, Weldon, Kirschling ve Muller, 1975). 1980-1990 yılları arasında da özel kredi sağlayan kuruluşların sayısında ve öğrenci borçlanmasında şaşırtıcı bir artış olmuş, 2000'li yıllarda da öğrenciye verilen federal hibe ve krediler artarak devam etmiştir (Zhou ve Mendoza, 2017).

Öğrenciye verilen eğitim kredileri ise hâlâ "Federal Öğrenci Fonu" kapsamında yapılanmakta ve bu fon, 2010 yilı verilerine göre ön ödemesiz ve kefilsiz olmak üzere yıllık \% 4.5-6.8 faiz oranı aralığında sabit faizli krediler sağlamaktadır. Maddi durumu yeterli olmayan başarılı öğrencilerin faiz yükünün bir kısmı da devlet tarafından karşılanabilmektedir. Kredi geri ödemeleri, öğrencinin eğitiminin tamamlanmasından sonra başlamaktadır. Bununla birlikte, Amerikan bankalarının sunduğu eğitim kredileri de öğrenciler için önemli bir kaynak olarak kabul edilmekte, ancak değişken faiz oranı 
veya daha yüksek faiz oranı üzerinden geri ödemeler yapılmaktadır. Amerikan bankalarının sağladığı eğitim kredilerinin geri ödemeleri mezuniyet sonrasında başladığı gibi, bazı bankalar öğrencinin mezun olmasından önce de geri ödemeleri talep edebilmektedir (Teker ve Teker, 2012), bu durum da öğrencinin eğitim hayatını sekteye uğratmaktadır.

Amerika yükseköğretim harcamalarının 2015-2016 eğitim yılı kamu, özel ve hane halkı verileri incelendiğinde, Amerika üniversite eğitim finansmanının büyük bir çoğunluğunun öğrenci ve hane halkı tarafindan karşılanan özel finansman kaynakları ile sağlandığı görülmektedir. Özel kaynaklardan gelen harcamalar (\% 64.8) ve hane halk1 harcamaları (\% 46.3) kamu harcamalarından (\% 35.2) daha fazladır (Şekil 3). Ayrıca üniversite öğrencisinin kişi başı eğitim harcaması 30.003 \$ iken, GSYİH'e oranı ise \% 2.58 'dir (OECD, 2020a).

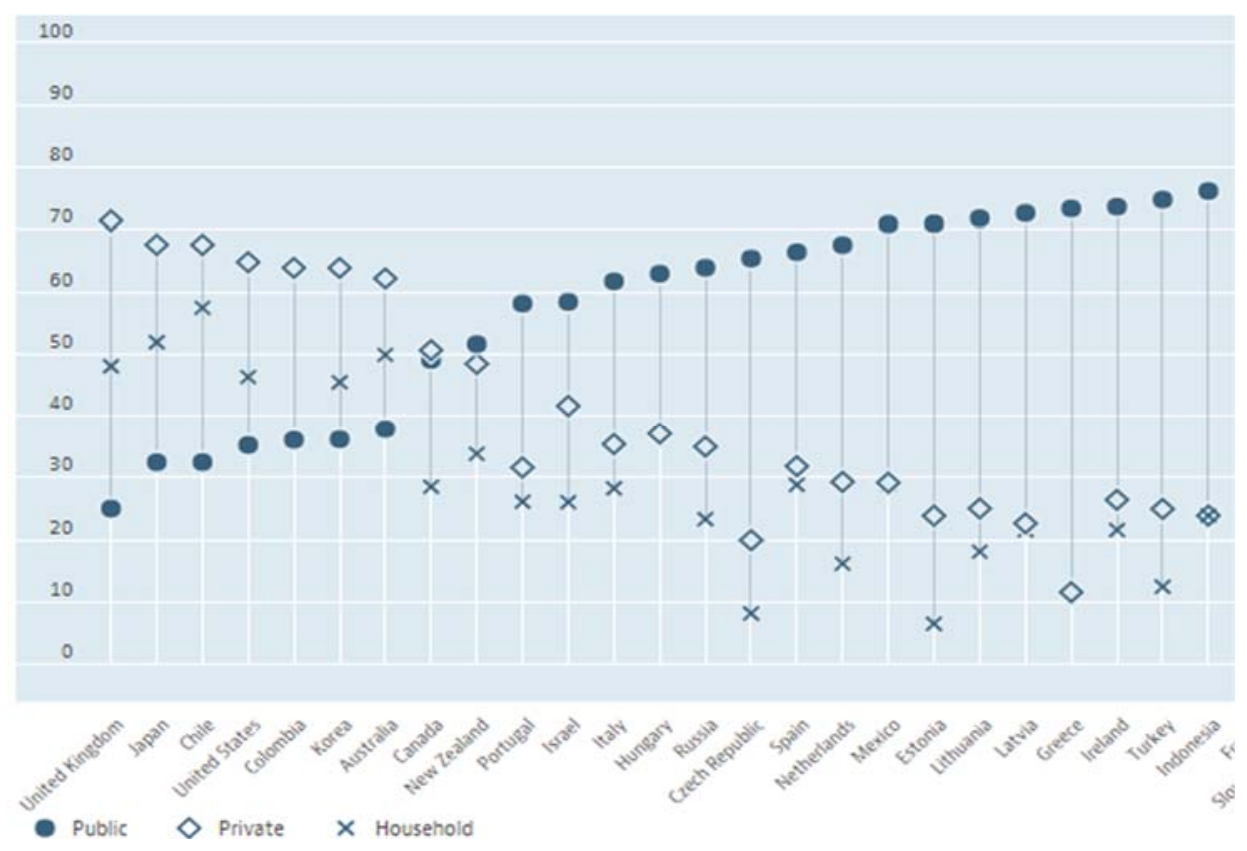

Kaynak: OECD, 2020a. Spending on tertiary education (indicator). doi: 10.1787/a3523185.

Şekil 3. Yükseköğretime yapılan harcamalar, Kamu/Özel/Hane halkı eğitim harcamalarının yüzdesi, 2016. 
Şekil 3'deki değerler incelendiğinde, Amerika'nın yükseköğretim faaliyetini özel kaynaklar ve hane halkı kaynakları ile İngiltere, Japonya ve Kore gibi yükseköğretim faaliyetini güçlü bir şekilde yürüten ülkeler sıralamasını yakından takip ettiği görülmektedir. Kendi yükseköğretim finansmanını karşılamak durumunda olan öğrencilerin yükseköğretime katılım oranları incelendiğinde ise yine bu ülkelerin (Japonya, ABD, İngiltere) yükseköğretime katılım sağlayan öğrenci sayılarının, yükseköğretim finansının büyük çoğunluğu kamu tarafından karşılanan Türkiye’den daha fazla olduğu tespit edilmektedir (OECD, 2020b).

Amerika'da yükseköğretim finans kaynaklarından biri de üniversite-sanayi işbirliği ile edinilen katkıdır. Üniversite-sanayi işbirliğinin kökenleri on yedinci yüzyıl İngiltere'sine uzanmakta, daha sonra ilk örnekleri 1800'lerde Amerika'da yaşanan sanayi devrimiyle Avrupalı şirketlerin Harvard, MIT gibi üniversitedeki araştırmacılarla birlikte çalışmalarıyla başladığı iddia edilmektedir. Ürettikleri bilgiden kâr etmek isteyen akademisyenler üniversiteleri ekonomik fayda ilkesine göre işleyen işletmelere benzeterek üniversitelerin zamanla şirketleşmesine katkı sağlamıştır (Çınar ve Ağcakaya, 2016). Böylelikle üniversite-sanayi işbirliğinden elde edilen kazanç üniversiteye tahsis edilmiş, alternatif gelir kaynağı oluşturmuştur.

Üniversite-sanayi işbirliğine örnek bir uygulama da teknoloji geliştirme bölgeleri (TGB) olan teknoparklardır. Üniversite arazilerinde faaliyet gösteren teknoparklar, işletmelerin üniversitelerin alt yapılarından yararlanarak ileri teknoloji uygulamaları geliştirdikleri bölgelerdir. TGB'de üniversiteler girişimcilere fiziki alan ve hizmet sunarak nitelikli ticari ürün ve hizmet geliştirmelerine olanak sağlamaktadır. Buna karşın üniversiteler, kendi araştırmalarını yürütebilmek için de fon sağlayarak alternatif bir gelir kaynağı oluşturmaktadır (Alkan, 2009). Türkiye'de ise üniversitelerde TGB kurma çalışmaları 1980’lerde başlamış olmasına karşın (ODTÜ, 2017), 2001 yılında 4691 sayılı “Teknoloji Geliştirme Bölgeleri Kanunu” ile ancak bir yasal düzenleme hazırlanmış ve eyleme geçilmiştir (TGBK, 2001).

TGB'nin sağladığı alternatif gelirin yanı sıra yüksek düzeyde öğretim ücreti, kredi ve hibelerden oluşan cömert öğrenci desteği ile temsil edilen Amerikan yükseköğretim 
finans sistemi karmaşık bir sistemdir ve eyaletler arasında da farklılık göstermektedir (Herrington, 2015; Jungblut, 2017). Üniversitelerin bir kısmının öğrencilerin ödedikleri yükseköğrenim ücretlerinin doğrudan düşürmesi, bazılarının ise düşük maliyetli öğrenci kredisi kaynağı sağlaması bu farklılıklardan birkaçı olarak bilinmektedir (Herrington, 2015). Öğrenci borçlandırma finans sistemi ile ayakta tutulan Amerikan yükseköğretim sistemi, Amerikan mucizesinin arkasındaki en temel itici güçlerden birisi olarak görülmektedir (Türkmen, 2009) ve İngiltere'nin yükseköğretim finans sistemi ile farklı yönleri bulunsa da birçok noktada benzer özellikler taşıdığı analiz edilmiştir.

\section{İngiltere'de Yükseköğretim Finansmanı}

İngiltere, yükseköğretim kademesindeki uluslararası mobil öğrencileri cezbeden ve ülkeye çeken en popüler ülkelerden biri olduğu görülmekte, çoğu küresel sıralamada, dünyanın en büyük 50 araştırma üniversitesi arasında ABD'den sonra ikinci sırada yer almaktadır. Bununla birlikte, İngiltere'de yaşayan öğrenciler yurtdışında eğitim görme konusunda sıralamada diğer ülkelerin gerisinde kalmakta ve genel olarak kendi ülkelerinde yükseköğretime devam etmeyi tercih etmektedir (OECD, 2017b). İngiltere'de yükseköğretime bakıldığında, Amerika ile hem benzer hem farklı özellikler taşıdığı görülmektedir. Hiçbir eğitim ücreti alınmadığı İskoçya yükseköğretim sistemi hariç, sektör açık bir şekilde öğrenciye müşteri gözüyle bakmakta ve üniversiteler finans kaynağı olarak öğrenci kredisi tabanlı bir model ile sürdürebilirliklerini sağlamaktadır (Dearden, Machinb ve Vignolesa, 2009; Marginson, 2017). İngiltere'de üniversiteler kendi kendilerini yöneten kurumlardır (Yakar, 2015). İngiltere üniversiteleri bir şirket gibi öncelikle kendi yönetim organlarına cevap vermekte, iş planlarını oluşturmakta ve uygulamakta, zaman zamanda sermayelerini artırmak için finansal kuruluşlardan borçlanma üstlenmektedir. Amerika'daki üniversiteler gibi de para ve nitelikli öğretim üyeleri için diğer üniversiteler ile yarışmaktadır (Marginson, 2017).

Farklılıklarda ise ilk olarak, İngiltere'deki öğrencilerin çoğunlukla 18 yaşında, ABD'de olduğundan daha geç yükseköğretime girdiği görülmektedir (Wolf, 2015; Yakar, 2015) . İkincisi, devlet üniversiteleri, büyük kâr amacı olan ve olmayan özel sektör üniversitelerinin dışında, kurumsal misyon ve türde daha az çeşitlilik göstermektedir. 
Üçüncüsü, birbirinden ayrı olan İngiltere uluslarının istisnai durumları dışında, üniversitelerin sistem yönetimi merkeziyetçidir. Bir zamanlar "kamu" olarak tanımlanan ve şimdi yasal olarak "özel" olarak sınıflandırılan özerk olan İngiltere üniversiteleri, halen hükümet politikası, düzenlemesi ve fonları ile şekillenmektedir (Shattock, 2007). Devlet, Araştırma Mükemmellik Çerçevesi (Research Excellence Framework-REF) gibi performansa dayalı karşılaştırmalar yoluyla sistem şeklini, teşviklerini ve davranışlarını yönetmektedir. Dahası bu çerçevede İngiltere vatandaşları ve Avrupa Birliği öğrencileri için öğrenim ücretlerinde sabit bir tavan-taban ücreti mevcut olup, kurum tarafindan belirlenen ücret çeşitliliği de azaltılmaktadır (Marginson, 2017).

İngiltere'de öğretim hibeleri, hükümete bağlı İngiltere Yüksek Öğrenim Fon Konseyi (Higher Education Funding Council for England, HEFCE) tarafindan tahsis edilmekte ve ödenmektedir. Buckingham ve Law Üniversitesi dışında tüm üniversiteler HEFCE tarafından yönetilen fonlardan destek almaktadır (The European Education Directory, 2017). Öğrenci kredileri, gelir şartına bağlı olarak Öğrenci Kredi Şirketi (Student Loans Company, SLC) aracılığıyla işlenmekte, her okunan bölüme göre alınabilecek kredi miktarı değişmektedir. SLC ücreti doğrudan öğrenciye değil, üniversitelere ödemektedir. Ödenen ücret yüksek öncelikli programlar için ve sosyoekonomik düzeyi düşük öğrenciler için daha fazladır (Hauptman, 2007). Kredi alan öğrenciler ise üniversiteyi bitirip, belli bir kazanç eşiğine ulaştıkları andan itibaren vergi sistemiyle aldıkları krediyi ödemeye başlamaktadır (Wolf, 2015). İngiltere yükseköğretim sisteminde öğrenci harçları çok yüksek olmasına rağmen destek sistemleri iyi gelişmiştir (Korkmaz, 2021).

\section{Japonya'da Yükseköğretim Finansmanı İle İlgili Bulgular}

Japonya'da üniversiteler yüz yıldan fazla bir süredir hükümet tarafından kontrol edilen devlet kurumları olarak faaliyet göstermiştir. Üniversitelerin varlıkları devlete aittir ve öğretim üyeleri, idari personel devlet memuru olarak görev yapmaktadır. Millî Eğitim Bakanlığı, mali yılın sonuna kadar harcanması gereken bütçeyi ulusal üniversiteye tahsis etmekte ve harcama yetkisini üniversiteye bırakmaktadır (Maruyama, 2008). Özel sektör, Japonya'da modern yükseköğretimin başlangıcından beri önemli bir rol oynamıştır (Kaneko, 1997). Yükseköğretimin kitlesellikten evrensel erişime geçişi ile birlikte, Japon 
hükümeti küreselleşme ve piyasalaşma gibi postmodern eğilimler karşısında direnememiş, 2004 yılında üniversitelerde reform yapma kararı almıştır (Huang, 2016; Ohmori, 2015). Bu reform ile Japonya yükseköğretim sisteminin yapısında, işlevlerinde ve finansal araçlarında radikal değişiklikler yapılmış, üniversite finans kaynakları çeşitlendirilmiştir. Ayrıca kamu bünyesindeki 87 ulusal üniversitenin her birine 'Üniversite Şirketi Yasası' ile bağımsız şirket statüsü verilmiştir (Maruyama, 2008; Oba, 2013; Ohmori, 2015; Yonezawa, 2007). Böylelikle üniversiteler tüzel kişilik kazanmışlar; idari, mali ve akademik açıdan özerk bir yapıya sahip olmuşlardır. Üniversite bir taraftan kamu sektörünün bir parçası iken, diğer taraftan bağımsız bir şekilde yönetilmesi beklenen bir kurum haline dönüşmüştür. Millî Eğitim Bakanlığı hâlâ orta vadeli hedef ve planı onaylasa da, her üniversite kendi hedeflerini belirlemektedir. Üniversite personeli artık memur olmadığı gibi, maaşları ulusal ödeme standardına göre değil her üniversitenin kendi standartlarına göre belirlenmektedir (Maruyama, 2008). Üniversite varlıkları da yasal olarak şirketleşen üniversiteye ait olmasına rağmen, Eğitim Bakanlığı denetim rolünden vazgeçmemiştir (Oba, 2013; Yonezawa, 2007). Üniversiteler bir taraftan şirketleşerek kamusallıktan uzaklaşmakta diğer taraftan hükümete hesap verme gerekliliği ile ikilemde kalmaktadır. $\mathrm{Bu}$ durumda da üniversiteler kamusal ve finans açısından özerkliğini tam olarak sağlayamamaktadır. Dolayısıyla yeni sistemin istikrarsız olarak görülmekte, üniversiteler, hükümet ve diğer paydaşlar arasında bir güç oyunu olduğu belirtilmektedir (Murasawa, 2002; Yonezawa, 2007). Yeni bir kamu yönetimi çerçevesi altında "bağımsız bir idari şirket" planının getirilmesi yoluyla devlet kurumlarının küçültülmesi planı, ulusal ve çoğu yerel kamu kurumlarına uygulanmıştır (Murasawa, 2002).

Ulusal üniversitelerin dönüştürülmesi politikası ile temelde öğrenim ücretlerine ve harçlara bağımlı olan çok sayıda özel yükseköğretim kurumunun geliri artmış, hem ulusal hem de yerel kamu sektörlerinde hükümet harcamalarının miktarında istikrarlı bir düşüş gözlenmiştir (Huang, 2017). Bununla birlikte öğrenciler ve aileleri eğitim harcamalarına çok daha fazla katkıda bulunmaya başlamıştır (Asonuma, 2002). Birçok OECD ülkesiyle karşılaştırıldığında, Japonya'da yükseköğretimdeki kamu harcamaları OECD ülkelerinin 
çoğundan daha düşük olduğu görülmektedir (Huang, 2017). Şekil 3'te görüldüğü gibi Japonya İngiltere'den sonra üniversite eğitim finansmanının büyük bir çoğunluğunu özel kaynaklardan sağlayan ülkelerin başında gelmektedir. Veriler incelendiğinde, Japonya'nın yükseköğretim finansmanını \% 32.4'ünü kamudan, \% 67.6'sını özel kaynaklardan gelen finanstan ve \% 51.9'unu hane halkından karşıladığg görülmektedir. Ayrıca üniversite öğrencisinin kişi başı eğitim harcaması 19.289 \$ iken, GSYİH’e oranı ise \% 1.39 'dur (OECD, 2020a).

Üniversitelerin yaklaşık \% 68 oranında olan kamu dışı finans kaynağı farklı öğrenci türleri için geliştirilen çeşitli programlar ile sağlanmaktadır. Bu programlardan öğrencilere faizsiz ve uzun vadeli faizli kredi veren, burs imkanları sunan 'Eğitim, Kültür, Spor, Bilim ve Teknoloji Bakanlı̆̆ (Monbukagakusho-MEXT)' ile hükümet, üniversiteler ve işletmeler ile işbirliği yaparak öğrenciye ve yükseköğretim kurumlarına destek veren 'Japonya Öğrenci Hizmetleri Organizasyonu (JASSO)' nun ülkenin önde gelen yükseköğretim finans kaynaklarından olduğu bilinmektedir. MEXT yerli ve yabancı öğrencilere ‘burslu yabancı öğrenci sistemi' ile beş kategoride burs vermektedir. Bunlar (MEXT, 2016): (i) Japonya Hükümeti Araştırma Bursu, (ii) Japonya Hükümeti Lisans Bursu, (iii) Japonya Hükümeti Teknik Meslek Yüksekokulu Bursu, (iv) Japonya Hükümeti Meslek Yüksekokulu Bursu ve (v) Japonya Hükümeti Japonca ve Japon Kültürü Araştırmaları Bursu'dur. Ayrıca kendini finanse eden uluslararası öğrencilere ders indirimi ve muafiyet gibi mali yardım verilerek, ülkeye uluslararası öğrenci gelişi desteklenmektedir.

Yükseköğretimin bir diğer önemli finans kaynağı olan Japonya Öğrenci Hizmetleri Organizasyonu (JASSO), MEXT bünyesinde 1 Nisan 2004'te bağımsız bir idari kurum olarak kurulmuştur. Eğitimi destekleyen, ulusal ve uluslararası öğrencilere yönelik burs programları sunan farklı kurumların birleşmesinden oluşmuştur. Bu kurumlar Japonya Burs Kuruluşu, uluslararası öğrencilere yönelik destek programları sunan Uluslararası Eğitim Derneği, Yurtiçi ve Yurtdışı Öğrenci Merkezi, Uluslararası Öğrenci Enstitüsü ve Kansai Uluslararası Öğrenci Enstitüsüdür (JASSO, 2017). Bu bursların amacı, başarı motivasyonu yüksek ve yetenekli Japon öğrencileri yurtdışında okumaya teşvik etmek ve 
özellikle diğer ülkelerde ve bölgelerde okuyan Japon öğrencilerin sayısını 2020'ye kadar 120.000 kişiye çıkarmaktır (Huang, 2016). Böylelikle Japonya'nın kamu diplomasisi adına uluslararası tanıtımını yapmak da amaçlanmaktadır.

JASSO, ayrıca her tür yükseköğretim kurumundaki Japon öğrenciler için faizli (Kategori I) ve faizsiz (Kategori II) şeklinde 'Burs Kredisi Programları' sunmaktadır. Sadece Japon öğrencilere değil, Japonya'da okumak isteyen uluslararası öğrencilere de mali destek sağlamaktadır (Huang, 2017). Bu yükseköğretimde uluslararasılaşma politikası ile 2005'te yükseköğretime 121.012 uluslararası öğrenci kaydı yapılmışken, JASSO'nun sağladığı burslar ile bu sayı 2015'te 152.062'ye ulaşmıştır (Yamada, 2017). Hükümet tarafından başlatılan 'Global 30’ programı ile de Japonya 2020’ye kadar 300.000 yabancı öğrenci yükseköğretime çekmeyi hedeflemektedir. Uluslararası öğrenci değişimini teşvik etmesinin yanı sıra JASSO, bağımsız bir idari kurum olarak, daha elverişli öğrenme ortamı ile yükseköğretim kurumlarının geliştirilmesi ve okullar ile hükümet, üniversite ve sanayi işbirliği gibi çok çeşitli etkinliklerde de önemli rol oynamaktadır (Huang, 2017). Bu işlevleri ile de Japonya yükseköğretim finans mekanizmasının önemli bir parçası haline gelen JASSO, yetenekli yabancı öğrencileri ülkeye çekmenin ötesinde ülkeye kazandırdığı uluslararası araştırmacılar ile uluslararası araştırma ağlarının gelişmesine, ortak üniversite girişimlerinin kolaylaşmasına, ayrıca Japon üniversite ve şirketlerinin dünya çapındaki prestijini arttırmaya da katkı sağlamaktadır (Yamada, 2017).

Yükseköğretim finans modeli ile İngiltere ve ABD’ye oranla öğrencilere daha geniş yelpazede alternatif sunan bir sisteme sahip olan ülke Japonya'dır. Japonya'nın yükseköğretim finans modeli ile mevcut yükseköğretim kayıt oranında 18 yaşındaki nüfusun yaklaşık \% 80'ine ulaşılmakta, dolayısıyla yükseköğretime neredeyse evrensel erişimin sağlanmasına katkıda bulunulmaktadır. Ayrıca yükseköğretim finans modelinin çeşitliliği ile Japonya, ABD ve İngiltere'ye oranla her geçen gün artan ivmeyle ülkeye öğrenci çekmektedir (Huang, 2016). 


\section{TARTIŞMA ve SONUÇ}

Gelişmekte olan ve gelişmiş ülkelerin çoğunda neo-liberal ekonomik reformların ortaya çıkışı, yükseköğretime ayrılan kamusal bütçelerin daralmasına yol açmışır (Tilak, 2012). Kaliteyi güvence altına alarak, niceliksel genişlemenin sürdürülebilmesinin sadece kamu finansmanı ile sağlanması mümkün görülmeyeceği söylenebilir (Huang, 2016). Araştırmada farklı finans modellerine sahip olan ülkelerin verileri incelendiğinde, yükseköğretimin maliyetini ABD'de \% 35.2'sini kamu karşlarken \% 64.8'i özel kaynaklardan tahsis edilmektedir. Bu oranların İngiltere'de \% 25.0 kamu ve \% 71.4 özel kaynaklar, Japonya'da \% 32.4 kamu ve \% 67.6 özel iken Türkiye'de ise bu oranın \% 74.8 kamu ve \% 24.9 özel kaynaklardan oluştuğu görülmektedir (OECD, 2020a). Eğitim alan nüfus ve ekonomik göstergeler açısından ortalama değerlerden daha yüksek bir değere sahip olan ülkeler karşılaştırmaya dâhil edilmemiştir. Türkiye'de diğer ülkelere kıyasla kamu harcamasının çok daha yüksek olduğu görülmekte ve kamu-özel ve hane halkı maliyet payı dağılımlarında bu oranların daha dengeli olması gerektiği düşünülmektedir. Öğrenci sübvansiyonları şeklinde kamuoyu desteği alan, dolayısıyla herhangi bir öğrenim ücreti ödemeyen Norveç ve Finlandiya gibi İskandinav ülkeleri (Garritzmann, 2016) analize dâhil edilmemiştir. Bu ülkeler eğitim alan nüfus ve ekonomik göstergeler açısından ortalama değerlerden daha yüksek bir değere yani eğitim harcamalarının GSYIHH'ya oranında OECD ülkelerinden farklılık göstermektedir. OECD ülkelerinde ortalama 5.2 iken Finlandiya'da 5.7 ve Norveç'te 6.2'dir (OECD, 2017b). Yükseköğretim finans kaynağının büyük bir çoğunluğunu Türkiye'den farklı olarak özel kaynaklarla sağlayan ABD, Japonya ve İngiltere'de öğrencilere kredi sağlama, öğrenciyi borçlandırma politikası çeşitlilik göstermekte ve öğrencilere farklı seçenekler sunmaktadır. Türkiye'de de tek tip kredi sağlayan Kredi Yurtlar Kurumu aynı işlevi yerine getirse de diğer ülkelerin modellerine göre oldukça yetersiz kalmaktadır. Türkiye'de öncelikle ulusal ve uluslararası öğrencilere farklı kredi imkânları sunan, orta ve düşük gelirli ailelerin çocuklarına ve dezavantajlı bölgelerden üniversiteye başvuran öğrencilere yönelik farklı yaptırımlar uygulayan, ödeme sisteminde bu farklılıkları göz 
ardı etmeden standartlar belirleyen daha kapsamlı bir kurum kurulmalıdır. Kredi alan öğrencilerin belli bir geliri sağlayana kadar geri ödeme zorunluluğu olmamalı, belirlenen geliri elde etmesi mümkün olan yıla göre de ödemesi derecelendirilmelidir. Bu kurum ayrıca kamu finansmanının yükünü azaltırken, aynı zamanda uluslararası öğrenci çekme konusunda da çalışmalar yapma sorumluluğuna sahip olmalıdır.

Gelir yaratma kanallarını çeşitlendirmek adına devlet, sanayi ve üniversite işbirliğinde de farklı atılımlar yapılmalıdır. Üniversite-Sanayi işbirliği Türkiye'de diğer ülkelere göre çok geç başlamış olup, hala yeterince yaygınlaşstırılmamış ve aktive edilmemiştir. Alkan’a (2009) göre işbirliğin yeterince sağlanamamasında, sanayinin teknoloji talebinde bulunacak ve buna ihtiyaç duyacak kadar nitelikli olmamasının payı vardır. Başvurulan patent sayısını artırmak, teknolojik üretime katkı sağlamak amacıyla her üniversite sanayi işbirliği desteklenmelidir. Yatırımcıların üniversitelere destek vermesi sağlanmalı üniversitelerin de bilimsel araştırma temeline dayanarak yatırımcılar için ürün geliştirmeleri sağlanmalıdır. Üniversite sanayi işbirliğinin Ar-Ge çalışmalarında yeni girişim ve gelişmelerin olmasına katkı sağlayacağı öngörülmektedir. 


\section{KAYNAKLAR}

Akça, H. (2011). Yükseköğretimin finansmanı ve Türkiye için yükseköğretim finansman modeli önerisi. Yönetim ve Ekonomi, 19(1), 91-104.

Alkan, 2009. Yüksekögretim kurumlarında Ar-ge harcamaları ve finansman şekilleri. Devlet Bütçe Uzmanlığı Araştırma Raporu, Maliye Bakanlı̆̆ı, Ankara.

Altbach, P. G. (2005). The private higher education revolution: An introduction. P.G. Altbach and D.C. Levy (eds.), Private Higher Education: A Global Revolution, Rotterdam, Sense Publishers. 1-12.

Altbach, P. G., Reisberg, L., ve Rumbley, L. (2009). Trends in global higher education: Tracking an academic revolution. Paris: UNESCO.

Altundemir, M. E. ve Cibo, H. (2016). Yükseköğretimin finansmanı konusunda üniversitelerin görüşleri: YÖK yasa tasarısı çerçevesinde. Maliye Araştırmaları Dergisi, 1(3).

Arastaman, G. (2020). Yükseköğretimin finansmanı. Yükseköğretim üzerine düşünmek. (Ed. G. A. Baskan ve N. Cemaloğlu). Ankara: Pegem.

Asonuma, A. (2002). Finance reform in Japanese higher education. Higher Education, $43,109-126$.

Ateş, H. (2013). OECD ülkeleri ile Türkiye'nin yükseköğretim finansman sistemlerinin karşılaştırılması ve Türkiye için bir finansman modeli önerisi. Doktora Tezi, Hacettepe Üniversitesi Eğitim Bilimleri Enstitüsü, Ankara.

Baskan, A. G. Ve Sincer, S. (2014). Yeni YÖK Yasa tasarısı çalışmaları bağlamında Türkiye'deki yükseköğretim sisteminin değerlendirilmesi. Yükseköğretim ve Bilim Dergisi, 4(2), 67-72.

Baum, S. and Payea, K. (2005). Education pays 2004: The benefits of higher education for individuals and society. New York: the College Board.

Balaban, U. (2012). Türkiye'de yükseköğretim reformu ve ABD'de endüstri-üniversite ilişkisinin tarihi. Ankara Üniversitesi SBF Dergisi, 67(04), 025-061.

Bergen, B.M. and Zielke, D.D. (1979). Educational progress of basic educational opportunity grant recipients compared to non-recipients, The Journal Of Student Financial Aid, 1(9), 19-22.

Bevis, T.B.(2019). A world history of higher education exchange. Palgrave Macmillan. E-book https://doi.org/10.1007/978-3-030-12434-2 adresinden 03.03.2021 tarihinde elde edilmiştir.

Brennan, J. (2002). Transformation or Reproduction? Contradictions in the Social Role of the Contemporary University. In: Enders, J. and Fulton, O. eds. Higher Education in a Globalising World: International Trends and Mutual. 
Observation - A Festschrift in Honour of Ulrich Teichler. Higher Education Dynamics (1). Dordrecht, Netherlands: Springer, pp. 73-86.

Brennan, J. (2004). The social role of the contemporary university: Contradictions, boundaries and change. Ten years on: Changing education in a changing world. Center for Higher Education Research and Information (CHERI). Buckingham: The Open University Press.

Çaltekin, M. (2017). Teknoloji geliştirme bölgelerinde vergi ve sosyal güvenlik uygulamalart. İstanbul. E-kitap https://www.pkfistanbul.com/download/mehmet-caltekin-tgb-arge-vergiuygulama.pdf adresinden 28.02.2021 tarihinde erişilmiştir.

Çetinsaya,G.(2014). Büyüme, kalite, uluslararasılaşma: Türkiye yükseköğretimi için bir yol haritasl.

https://www.yok.gov.tr/Documents/Yayinlar/Yayinlarimiz/buyume-kaliteuluslararasilasma-turkiye-yuksekogretim-icin-bir-yol-haritasi.pdf adresinden erişilmiştir.

Çınar, F. ve Ağcakaya, S. (2016). Yükseköğretimin finansmanında alternatif stratejiler: Dünyadaki uygulamalar ve Türkiye'de mevcut durum üzerinden karşılaştırmalı bir analiz. Süleyman Demirel Üniversitesi Sosyal Bilimler Enstitüsü Dergisi, 23(1), 269-289.

Dearden, L., Machin, S. and Vignolesa, A. (2009). Economics of education research: a review and future prospects. Oxford Review of Education, 35(5), 617-632.

Doğan, D. (2013). Yeni kurulan üniversitelerin sorunları ve çözüm önerileri. Yükseköğretim ve Bilim Dergisi,3(2), 108-116.

DPT.(1984). Beşinci Beş Yıllık Kalkınma Planı (1985-1989). https://www.sbb.gov.tr/wp-content/uploads/2018/11/Be\%C5\%9FinciBe\%C5\%9F-Y\%C4\%B111\%C4\%B1k-Kalk\%C4\%B1nma-Plan\%C4\%B11985-1989.pdf adresinden 20.02.2021 tarihinde erişilmiştir.

Etzkowitz, H., 1983. Entrepreneurial Scientists and Entrepreneurial Universities in American Academic Science, Minerva, 21(2), 198-233.

Erdil, E., Pamukçu, M. T., Akçomak, İ. S. ve Erden, Y. (2013). Değişen üniversitesanayi işbirliğinde üniversite örgütlenmesi. Ankara Üniversitesi $S B F$ Dergisi, 68(02), 095-117.

Garritzmann J. L. (2016). The four worlds of student finance: A comparative descriptive overview of tuition fees and subsidies in 33 OECD countries. In: The Political Economy of Higher Education Finance. Palgrave Macmillan, Cham.

Gölpek, F. (2011). A new approach in higher education finance policy: cost sharing. Yüksekögretim Dergisi, 1(1), 25-33. 
Gür, B. (2016). Egemen üniversite. Amerika'da Yükseköğretim Sistemi ve Türkiye İçin Reform Önerileri. İstanbul: Edam.

Hauptman, A.M. (2007). Higher education finance: trends and issues. International Handbook of Higher Education, (In. Ed. P. G. Altbach and J.G.J.Forest). Dordrecht:Springer.

HEFCE, 2017. How teaching is funded. http://www.hefce.ac.uk/lt/howfund/ adresinden erişilmiştir.

Herrington, C. M. (2015). Public education financing, earnings inequality, and intergenerational mobility. Review of Economic Dynamics, 18(4), 822-842.

Huang, F. (2016). Changes and challenges to higher education financing in Japan. Centre for Global Higher Education Working Paper Series, 1-25.

Huang, F. (2017). Higher education financing in Japan: Trends and challenges. International Journal of Educational Development, 58, 106-115.

Hunt, C. (2011). National strategy for higher education to 2030. https://www.lenus.ie/handle/10147/120285 adresinden erişilmiştir.

Jacob, W. J., Neubauer, D. and Ye, H. (2017). Financing trends in Southeast Asia and Oceania: Meeting the demands of regional higher education growth. International Journal of Educational Development, 58, 47-63.

JASSO, 2017. History of JASSO. 17.11.2017 tarihinde http://www.jasso.go.jp/en/about/organization/history.html. adresinden erişilmiştir.

Johnstone, D. B. (2003). The economics and politics of cost sharing in higher education: comparative perspectives, Economics of Education Review, 23(4), 403-410.

Jungblut, J. (2017). The political economy of higher education finance. The politics of tuition fees and subsidies in OECD countries, 1945-2015. European Journal of Higher Education, 7(1), 96-99. doi:10.1080/21568235.2017.1265789

Kaneko, M. (1997). Efficiency and equity in Japanese higher education. Higher Education, 34, 165-181.

Karakütük, K. (2006). Yükseköğretimin finansman1. Milli Eğitim Dergisi, 171, 219- 42.

Karasar, N. (1999). Bilimsel araştırma yöntemi - Kavramlar, ilkeler, teknikler. Ankara: Nobel.

Karasar, N. (2013). Bilimsel araştırma yöntemi. Ankara: Nobel.

Kiper, M. (2010). Dünyada ve Türkiye'de üniversite-sanayi işbirliği. Ankara: Türkiye Teknoloji Geliştirme Vakfi Yayını.

Korkmaz, T. (2013). İngiltere eğitim sistemi. Ĕ̈itim Yapıları ve yönetimleri açısından çeşitli ülkelere bakış. Ed. Sefer Ada. Nurdan Baysal. Ankara: Pegem. 
Kurt, T. (2021). Eğitim finansmanının karşılaştırmalı analizi. Karşılaştırmalı Eğitim Tematik Bir Yaklaşım. (Ed. Murat Gürkan Gülcan ve Fatih Şahin). Ankara: Pegem.

Kurul, N. (2002). Eğitim finansmanı. Ankara: Siyasal.

Lee, J., Weldon, K., Kirschling,W.L. and Muller, J. (1975). State student incentive grant program issues in partnership. Education Commission of the States and the National Center for Higher Education Management Systems.

Lucas, C.J. (2006). American higher education. England: Plagrave Macmillan.

Lung, M. and Alexandra, N. L. (2012). Financing higher education in Europe: issues and challenges. Procedia-Social and Behavioral Sciences, 51, 938-942.

Marginson, S. (2017). Global trends in higher education financing: The United Kingdom. International Journal of Educational Development, 58, 26-36.

Maruyama, F. (2008). An overview of the higher education system in Japan. President of Center for National University Finance and Management, 1, 1-12.

Murasawa, M. (2002). The future of higher education in Japan: Changing the legal status of national universities. Higher Education, 43, 141-155.

MEXT, 2016. Statistical Abstract, 2015 edition National Printing Bureau, Tokyo. http://www.mext.go.jp/en/policy/education/highered/title03/detail03/_icsFil es/afieldfile/2012/06/19/1302653_1.pdf. adresinden erişilmiştir

Oba, J. (2013). University governance reforms in Japan-Incorporation of national universities. In RIHE International Seminar Reports, 19, 71-97.

ODTÜ, 2017. Türkiye'de Teknokentler. http://odtuteknokent.com.tr/tr/hakkinda/turkiyedeki-teknokentler sayfasından erişilmiştir.

OECD, 2017b. Education at a glance. http://www.oecdilibrary.org/education/data/education-at-a-glance/educational-financedatasets_c4e1b551-en adresinden erişilmiştir.

OECD, 2020a. Spending on tertiary education (indicator). doi: 10.1787/a3523185-en

OECD, 2020b. Education at a Glance 2020: OECD Indicators, OECD Publishing, Paris. https://doi.org/10.1787/69096873-en.

Ohmori, F. (2015). Japan and transnational higher education. International Higher Education, (37).

Özgün, M. (2021). Karşılaştırmalı yükseköğretim Karşılaştırmalı Eğitim Tematik Bir Yaklaşım. (Ed. M. G. Gülcan ve F. Şahin). Ankara: Pegem.

Palmedessa, A. (2017). American national identity, policy paradigms, and higher education: a history of the relationship between higher education and the United States, 1862-2015. Palgrave MacMillan. 
Psacharopoulos, G., Tan. J.P. and Jimenez, L. (1986). Financing education in developing countries: An exploration of policy options. Washington :World Bank.

Reisz, R.D. (2007). Legitimacy discourse and mission statements of private higher education institutions in Romania. (Eds. S.Slantcheva and D.C.Levy). Private Higher Education In Post-Communist Europe in Search of Legitimacy.

Shapiro, H.T. (2005) A larger sense of purpose: Higher education and society. Princeton University Press, Princeton.

Shattock, M. (2007). United Kingdom. In: Forest J.J.F., Altbach P.G. (eds) International Handbook of Higher Education. Springer International Handbooks of Education, vol 18. Springer, Dordrecht. https://doi.org/10.1007/978-1-4020-4012-2_13

Şenses, F. (2007). Uluslararası gelişmeler ışığında Türkiye yükseköğretim sistemi: temel eğilimler, sorunlar, çelişkiler ve öneriler. ERC Working Papers in Economics.

TCA. (1982). Türkiye Cumhuriyeti Anayasas1. https://www.tbmm.gov.tr/anayasa/anayasa_2018.pdf adresinden 01.03.2021 tarihinde edinilmiştir.

Teker, S. ve Teker, D. (2012). Yükseköğretim finansmanı: Türkiye için model önerileri. Doğuş Üniversitesi Dergisi, 13(2), 301-314.

Tekeli, İ. (2010). Tarihsel bağlam içinde Türkiye'de yüksekögretimin ve YÖK'ün tarihi.İstanbul: Tarih Vakfı Yurt Yayınları.

Tekeli, İ. (2011). Türkiye için eğitim yazıları. İstanbul: Tarih Vakfı Yurt Yayınları.

Tilak, J. B. (2012). Financing of higher education: Traditional versus modern approaches. Journal of Higher Education/Yüksekögretim Dergisi, 2(1).

TGBK. (2001). Teknoloji Geliştirme Bölgeleri Kanunu. https://www.mevzuat.gov.tr/MevzuatMetin/1.5.4691.pdf adresinden 23.02.2020 tarihinde erişilmiştir.

Trow, M. (2007) Reflections on the Transition from Elite to Mass to Universal Access: Forms and Phases of Higher Education in Modern Societies since WWII. In: Forest J.J.F., Altbach P.G. (eds) International Handbook of Higher Education. Springer International Handbooks of Education, vol 18. Springer, Dordrecht. https://doi.org/10.1007/978-1-4020-4012-2_13

Türkmen, F. (2009). Yükseköğretim sistemi için bir finansman modeli önerisi. Ankara: DPT.

Yakar, A. (2015). İngiltere eğitim sistemi. Karşılaştırmalı eğitim dünya ülkelerinden örneklerle. Ed. A. Türkoğlu. Ankara: Anı. 
Yamada, A. (2017). Japanese higher education reform trends in response to globalization and STEM demand. Comparative and International Higher Education Journal, 9, 14-22.

Yıldırım, C. ve Kaya, D. G. (2019). Ar-Ge Harcamalarının gelişimi ve Tr-AB üzerine bir değerlendirme. İktisadi ve İdari Bilimler Dergisi, 33(3), 791-812.

Yılmaz, T. ve Sarpkaya, R. (2016). Eğitim ekonomisi eleştirel bir yaklaşım. Ankara:Anı

Yonezawa, A. (2007).Japan. In: Forest J.J.F., Altbach P.G. (eds) International Handbook of Higher Education. Springer International Handbooks of Education, vol 18. Springer, Dordrecht. https://doi.org/10.1007/978-1-40204012-2_13

Yükseköğrenim Kredi ve Yurtlar Kurumu Kanunu. (1961). T. C. Resmi Gazete, 10887, 22 Ağustos 1961.

Yükseköğretim Kurulu, (2007). Türkiye'nin yükseköğretim stratejisi. https://www.yok.gov.tr/Documents/Yayinlar/Yayinlarimiz/Turkiyeninyuksekogretim-stratejisi.pdf adresinden erişilmiştir.

Yükseköğretim Kanunu Taslağı, (2013). Yükseköğretim Kurulu. https:/www.memurlar.net/common/news/documents/302681/yok-tasari.pdf adresinden erişilmiştir.

Y.Ö.K. (1981). 2547 numaralı Yükseköğretim Kanunu. 28.02.2021 tarihinde https:/www.mevzuat.gov.tr/MevzuatMetin/1.5.2547.pdf adresinden erişilmiştir.

Westerheijden, D.F., Stensaker, B and Rosa M.J. (2007). Quality assurance in higher education: Trends in regulation, translation and transformation. Springer, Dordrecht, NL.

Woodhall, M. (2007). Funding higher education: The contribution of economic thinking to debate and policy development. World Bank.

Wolf, A. (2015). Heading for the precipice: Can further and higher education funding policies be sustained. London: Policy Institute, King's College London.

Zhou, E. And Mendoza, P. (2017). Financing Higher Education in the United States. The Neoliberal Agenda and the Student Debt Crisis in US Higher Education: Indebted Collegians of the Neoliberal American University, 1.

Zubatsky, D. S. (2007). The history of American colleges and their libraries in the seventeenth and eighteenth centuries: A bibliographical essay.Illionis:Urbana.

\section{ORCID}

Bahar YAKUT ÖZEK (iD https://orcid.org/0000-0001-7699-8741

Sait AKBAŞLI (iD) https://orcid.org/0000-0001-9406-8011 


\section{SUMMARY}

Higher education, seen as an educational activity limited to the elites in the world, has become massive in time, it has no longer been an activity of raising only the elite and has met with a wide segment of the society. After the Second World War, countries saw higher education as a driving force for cultural development, social development and progress, initiating discussions on universal participation in higher education. Increasing access to higher education, which plays a key role in the development of countries, has brought problems in financing higher education. Countries have produced different financial systems to solve the financing problem that creates pressure on higher education systems. This study aims to analyze the models of leading countries in higher education and to make recommendations for overcoming financial difficulties that occur in Turkey's higher education financing system, finding non-public funds and diversifying the financial model.

The countries considered within the scope of the study were selected by taking four finance parameters, which Garritzmann (2016) determined by systematically comparing more than 70 features of the student-assistance system between 1995 and 2015 in 33 countries. According to these parameters, there are four different systems that finance education in higher education. In the first of these systems, the financial systems of countries that pay no tuition fees or have very low financial student support are examined. This higher education finance system is applied in Germany, Turkey, and many European countries. Turkey is handled under this system. In the second system, students receive generous public support and do not pay any tuition fees. This category includes Scandinavian countries such as Norway and Finland. These countries are not included in the analysis since they differ from the average values in terms of the population receiving education and economic indicators.

This third category is characterized by the high level of tuition fee, loan and grant alternatives offered to the student. Many Anglo-Saxon countries, the United States, and the United Kingdom fall under this category of higher education funding models. In this context, US and UK higher education financing models have been examined. The fourth system, on the other hand, requires paying a high tuition fee, yet it is a finance model that does not have any public student support applications. This category includes Latin American countries, Japan and South Korea. Within the scope of this system, the Japanese higher education finance system was analyzed in the study. In the study, the relevant literature was scanned and the data were obtained by scanning documents.

Unlike Turkey, vast majority of higher education financial resources is provided from private sources in the USA, Japan and the UK, and the policy of providing loans to students and borrowing students varies and offers a wide range. These countries, which have institutions that offer different alternatives in providing loans and repayment to national and international students, are the countries that attract the most international students in the world with the diversity they provide in higher education. Although the Credit and Dormitories Institution fulfills the same function by providing a uniform loan in Turkey, it is quite inadequate compared to the models of other countries. 
Primarily in Turkey, a more comprehensive institution, offering different loan opportunities to national and international students, children of middle and low-income families and students applying to university from disadvantaged regions, should be established by setting standards without ignoring these differences in the payment system. Students who receive a loan should not be obliged to repay until they provide a certain income, and their payment should be graded according to the year in which the specified income is possible. This institution should also have the responsibility to work on attracting international students while reducing the burden of public funding. In many developed countries, "international student transfer to higher education" is seen as a serious economic gain. Also, Turkey should develop a funding system that can compete with other countries in order to take its place in this market. In addition, different initiatives should be taken in cooperation within the state, industry and universities in order to diversify the income generation channels. Investors should be provided to support universities, and universities should develop products for investors based on scientific research. 